\title{
The Role of Metabolite in Bioequivalence Decision Making
}

\section{Qaisi AM ${ }^{1 *}$, Tutunji $\mathbf{L}^{2}$, Tutunji $\mathbf{M}^{3}$ and Mohsen $\mathbf{M A}^{4}$}

${ }^{1}$ Department of Pharmaceutical Sciences, Faculty of Pharmacy, The University of Jordan, Amman, Jordan

${ }^{2}$ Department of Pharmaceutics and Pharmaceutical Technology, Faculty of Pharmacy, The University of Jordan, Amman, Jordan

${ }^{3}$ Chemistry Department, Faculty of Science, The University of Jordan, Amman, Jordan

${ }^{4}$ Clinicalquest Clinical Research Services, Amman, Jordan

\begin{abstract}
Purpose: To investigate whether the combined concentrations of the parent drug and its corresponding metabolite impacts the experimental design of bioequivalence studies.

Methods: Enalpril and sildenafil were selected to assess bioequivalence as both drugs have active metabolites. The bioequivalence study of enalpril was conducted under fasting conditions, while the bioequivalence assessment of sildenafil was conducted under both fasting and fed conditions. For the three studies, the bioequivalence criteria of $80-125 \%$ was applied to assess the parent compounds alone, the active metabolites alone, and both the parent drugs and the active metabolites.
\end{abstract}

Results: Similar statistical results to assess bioequivalence were obtained for the parent drug, metabolite, and the sum of the parent drug and metabolite for AUC. In the case of $C_{\max }$, the intra subject variability of the bioequivalence statistical results with regards to the metabolite and the sum of the parent and the metabolite was lower than that for the parent drug while the power of the bioequivalence decision was higher for the metabolite and the sum of the parent drug and the metabolite.

Conclusions: An improved intra subject variability resulted in higher power with a smaller sample size in the $\mathrm{C}_{\max }$ values with regards to decision making in bioequivalence studies.

Keywords: Bioequivalence; Metabolite; Enalpril; Sildenafil; Power; Sample size

\section{Introduction}

Bioequivalence studies have been used to establish therapeutic equivalency of a generic drug product after modifying an existing formulation of an innovator product. In general, bioequivalence studies are usually popular because they cost much less than clinical trials that evaluate efficacy [1]. Classically, bioequivalence assessment relies on the concept of average bioequivalence. In most cases, bioequivalence studies are carried out focusing on the measurement of the parent drug. Even though the role of the metabolite in the assessment of bioequivalence has been the subject of many discussions, it still remains a controversial issue. The basic argument in favor of the use of the parent compound for bioequivalence assessment relies on the fact that the concentration - time profile for the parent drug is more sensitive to detect differences in formulation performance than the metabolite [2].

When the administered drug is either not metabolized or is the only active substance, the parent drug is used for the assessment of bioequivalence. There are situations where either both parent drug and metabolite data should be measured. These situations include: (a) the parent drug levels in biological fluids are too low to allow accurate analytical measurement, (b) the parent drug is unstable in the biological matrix, (c) the parent drug is an inactive produg, (d) the formation of the metabolite occurs rapidly, and (e) the metabolite contributes significantly to the net activity and the underlying pharmacokinetic system is not linear [2].

\section{Drug regulatory view: metabolites in bioequivalence}

The most recent guidance from the US FDA requests that the parent compound is measured. The rationale for this recommendation is that the parent drug is more sensitive to changes in formulation performance compared to the metabolite. Only when the metabolite is formed as a result of gut wall or other presystemic metabolism and the metabolite contributes to safety and efficacy is the metabolite measured to provide supportive evidence. In all other instances, only the parent drug is measured for bioequivalence $[3,4]$.

It has been demonstrated that the application of the $0.80-1.25$ bioequivalence limits to the sum of parent drug and metabolite may have misleading results $[1,2]$. It is suggested that wherever a metabolite is deemed feasible to include in the bioequivalence assessment, the $90 \%$ confidence interval should be applied to the parent compound and its metabolite separately. This may be due to the fact that the pharmacokinetics of the metabolite may be different from the parent compound [1]. It is worth noting that some of the recent trends in bioavailability / bioequivalence studies have suggested the resurgence of the use of metabolite pharmacokinetic data in making the bioavailability comparison and bioequivalence assessment [3].

The European Agency for the Evaluation of Medicinal Products' guidance paper states that the applicant must measure the parent compound. Metabolites are required in the following cases: (i) if the concentration of the parent drug is too low; and (ii) if the parent compound is unstable or half-life is too short. If bioequivalence is to be based upon the metabolite, it must be justified in each case [4].

*Corresponding author: Qaisi AM, Department of Pharmaceutical Sciences, Faculty of Pharmacy, the University of Jordan, Amman, Jordan, Tel: +962-65355000; E-mail: amqaisi@ju.edu.jo

Received March 18, 2015; Accepted April 15, 2015; Published April 22, 2015

Citation: Qaisi AM, Tutunji L, Tutunji M, Mohsen MA (2015) The Role of Metabolite in Bioequivalence Decision Making. J Bioequiv Availab 7: 158-163. doi:10.4172/ jbb.1000232

Copyright: ( 2015 Qaisi AM, et al. This is an open-access article distributed under the terms of the Creative Commons Attribution License, which permits unrestricted use, distribution, and reproduction in any medium, provided the original author and source are credited. 
In 1992, the Health Protection Branch Guidelines for Canada established the following criteria for immediate-release and modifiedrelease formulations. The determination of bioequivalence is based on measurement of the active ingredient, or its metabolite, or both, as a function of time. Normally, the parent compound is sufficient, but in some cases the metabolite could be required. When a prodrug is administered, the active metabolite should be measured [4].

The present study demonstrates that the role of the metabolite in bioequivalence contributes to the choice of appropriate pharmacokinetic and statistical designs and in optimizing the intrasubject variability of $\mathrm{C}_{\max }$ values, as well as in reducing sample size and enhancing power.

\section{Study design}

Enalapril and sildenafil were chosen to assess the bioequivalency using pharmacokinetic data obtained from the parent drug, the metabolite, and the sum of the parent drug and the metabolite after changing to $\mathrm{nM}$ concentration.

\section{Enalapril}

Enalapril maleate is an anti-hypertensive prodrug which is deesterified in the liver to an active diacid form enalaprilat [5]. Enalaprilat is an active ACE inhibitor that has been shown to be effective in the treatment of hypertension and congestive heart failure by dilating peripheral vascular resistance without causing significant changes in the heart rate or cardiac output. Following oral administration of enalapril in healthy volunteers, absorption is rapid. The terminal halflife of enalapril is approximately 2 hours after a single oral dose of 10 mg, maximum plasma concentrations of enalapril are reached 1 hour and it is not detected above $10 \mathrm{ng}$ after 4 hours. However, enalaprilat is detectable for up to 72 hours and has a half-life of approximately 30 35 hours [6]. Plasma enalaprilat concentrations are reportedly linearily related to the administered dose over the therapeutic range $(2.5-40 \mathrm{mg})$ [7].

\section{Sildenafil}

Sildenafil has been approved in various countries, including the US and Europe, for the treatment of pulmonary arterial hypertension. It is also approved for the treatment of erectile dysfunction. Oral sildenafil is rapidly absorbed with a $\mathrm{C}_{\max }$ observed within 1 hour after the dose in the fasted state. The mean absolute bioavailability of sildenafil capsules is about $41 \%$ in humans; animal studies suggest bioavailability is moderate because of extensive presystemic metabolism. In healthy human volunteers, food slows drug absorption but does not affect the area under the plasma concentration - time curve (AUC). AUC and $\mathrm{C}_{\max }$ values are dose-proportional over single sildenafil doses from 1.25 to $200 \mathrm{mg}$. Elimination of sildenafil is primarily by metabolism, with a biexponential decrease in plasma concentrations and an elimination half-life of 3 to 5 hours. Less than $2 \%$ of a dose is found in the urine as the parent drug; $80 \%$ of a dose is found in the faeces and $13 \%$ in the urine as metabolites. N-demethylation by CYP3A4 is the major route of the metabolism; CYP2C9 provides a minor route. The active $\mathrm{N}$-demethylated metabolite makes up to $20 \%$ of the activity of a sildenafil dose, having $50 \%$ of the activity of the parent drug and existing in concentrations that are $40 \%$ those of the parent drug. Sildenafil does not appear to accumulate after daily administration $[8,9]$.

\section{Materials and Methods}

\section{Subjects}

The studies were subject to ethics review, and each subject gave his signed informed consent. The study was approved by the Ethics Committee of the bioequivalence center and was in accordance with the Declaration of Helsinki (1964) as revised in Tokyo (1975), Venice (1983), Hong Kong (1989), and Somerset West, RSA (1996). Adult healthy males were included in the mentioned studies. They were required to pass physical examination criteria and not to take any medication and alcohol for at least 1 week prior to the study. Before the study they fasted for $12 \mathrm{~h}$ with free access to water. Volunteers stayed at the hospital for during each period of each study watching television and reading. The pharmacokinetic data were processed, and the bioequivalence of drugs was estimated using conventional methods.

\section{Analytical methods}

Plasma levels of enalapril, enalaprilat, and the internal standard bisoprolol were determined by API 5000 LC-MS/MS after protein precipitation with acetonitrile. The mobile phase consisted of $70 \%$ methanol and $30 \%$ of a mixture of $20 \mathrm{mM}$ ammonium acetate and $0.2 \mathrm{mM}$ formic acid, while the stationary phase was a RP-C18 column $(50 \times 4.0 \mathrm{~mm}$ ID, $5 \mu \mathrm{m})$. The column was kept at $60^{\circ} \mathrm{C}$, while the autosampler temperature was $4^{\circ} \mathrm{C}$. The flow rate was $0.5 \mathrm{ml} / \mathrm{min}$. The plasma levels of the analytes were measured after a single dose of $20 \mathrm{mg}$ enalapril tablets under fasting conditions.

Plasma levels of sildenafil, $\mathrm{N}$-desmethyl sildenafil, and the internal standard bisoprolol were determined by API 5000 LC-MS/MS after protein precipitation with acetonitrile. The mobile phase consisted of $55 \%$ methanol and $45 \%$ of a mixture consisting of $20 \mathrm{mM}$ ammonium acetate and $53 \mathrm{mM}$ formic acid, while the stationary phase was a RPC10 column $(30 \times 4.0 \mathrm{~mm}$ i.d, $5 \mu \mathrm{m})$. The column was maintained at $40^{\circ} \mathrm{C}$, while the autosampler temperature was $4^{\circ} \mathrm{C}$. The flow rate was $0.5 \mathrm{ml} / \mathrm{min}$. The plasma levels were measured for the determination of bioequivalence after a single oral dose of $100 \mathrm{mg}$ sildenafil under both fasting and fed conditions.

\section{Bioequivalence analysis}

Bioequivalence was assessed on log-transformed data using the $90 \%$ confidence interval (two one-sided test) for the parent compound, the active metabolite, and the sum of the parent and metabolite of both drugs after conversion of the concentrations to nanomolar.

\section{Results}

The results of the bioequivalence studies conducted are illustrated in (Figures 1-4). Figure 1 shows the mean concentrations versus concentrations for both the test and reference for enalapril, while Figure 2 shows the mean concentrations versus time for both the test and reference for the active metabolite enalaprilat. Figure 3 shows the mean concentrations versus time for both test and reference of sildenafil under fasting conditions, whereas Figure 4 illustrates the mean concentrations versus time for both test and reference of sildenafil under fed conditions.

The pharmacokinetic parameters for enalapril and its active metabolite enalaprilat are summarized in Table 1, while pharmacokinetic parameters for sildenafil and its active metabolite are summarized in Table 2 (under fasting conditions) and in Table 3 (under fed conditions).

The statistical results for enalapril and its metabolite enalaprilat are summarized in table 4 , while the statistical results for sildenafil and its metabolite $\mathrm{N}$-desmethyl sildenafil are summarized in table 5 (under fasting conditions) and Table 6 (under fed conditions). 


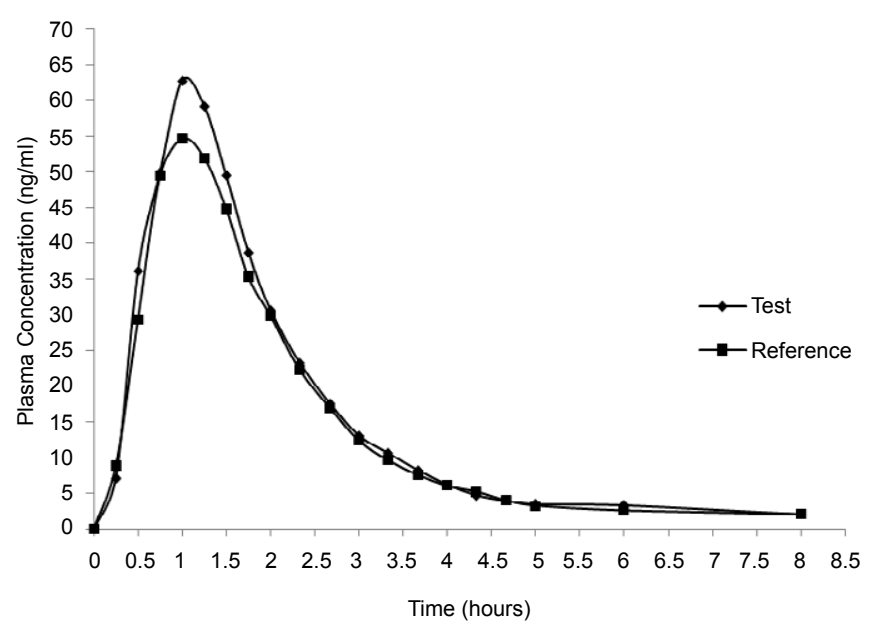

Figure 1: Mean plasma concentrations ( $\mathrm{ng} / \mathrm{ml}$ ) of enalapril versus time (hours) of the test and reference products after a single oral dose of $20 \mathrm{mg}$ enalapril tablet $(n=26)$ under fasting conditions.

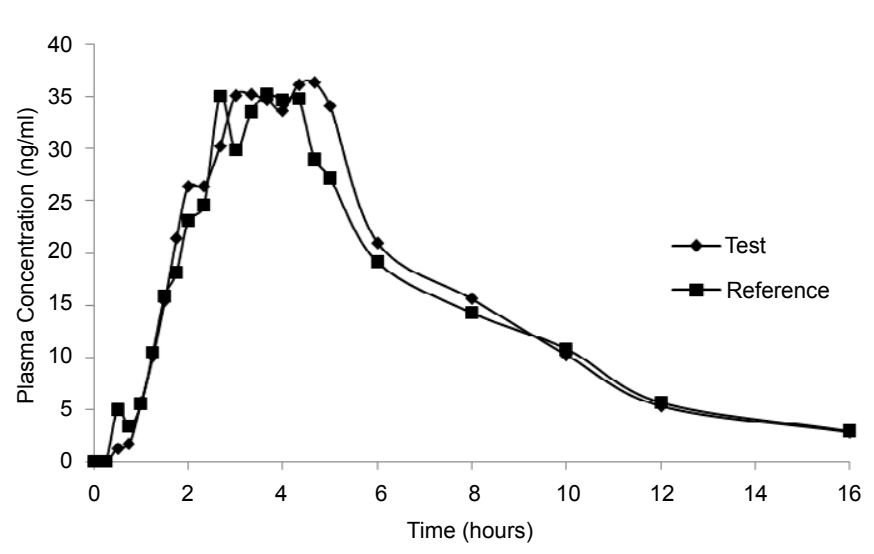

Figure 2: Mean plasma concentrations of enalaprilat $(\mathrm{ng} / \mathrm{ml})$ versus time (hours) for the test and reference products after a single oral dose of a $20 \mathrm{mg}$ enalapril tablet $(n=26)$ under fasting conditions.

Comparable results with regards to intrasubject variability were obtained when $\mathrm{AUC}_{0 \rightarrow \infty}$ and $\mathrm{AUC}_{0 \rightarrow \mathrm{t}}$ were evaluated. However, intrasubject variability was lower when either the metabolite(s) was measured alone or when the combination of both the active drug ingredient with its corresponding metabolite was evaluated. The results showed improved intrasubject variability and predicted lower sample size while enhancing the power especially with respect to $C_{\max }$ values.

\section{Discussion}

Bioavailability and bioequivalence studies are perhaps the most heavily regulated areas within the discipline of drug metabolism and pharmacokinetics, which supports a large sector of drug development and research [10,11]. Much has happened in recent years towards determining ultra-trace concentrations of drug analytes and their corresponding metabolites, which greatly enhanced pharmacokinetic data quality. At the interface between science and regulations, problems still occur due to: (1) regulations development paralleled the advancement of the bioanalytical science, which is constantly enjoying novel technological advancement, (2) experiments resulting in pharmacokinetic data were never looked upon holistically starting by the experimental design, conduct, analysis, and data management; the role of metabolite data for example remained unresolved and inconclusive.

Similar to other relevant issues, the role of the metabolite in bioequivalence studies continued to be the subject of much debate. Inclusion of metabolite pharmacokinetic data has been in existence since the early inception of international consortium in 1989 and 1992 to discuss bioequivalence decision making despite the interesting remarks pertaining to the use of the metabolite data.

In addition to dose-dependent metabolism/polymorphic metabolism, particularly with drugs which undergo first-pass metabolism, potential saturation of first-pass metabolism exists. This may be complicated by the existence of polymorphic metabolism, due to the existence of poor metabolizers as well as extensive or fast metabolizers. This will greatly impact the intra-subject variability, sample size, and the power taken into consideration in the bioequivalence decision making.

In view of the results of previous studies, which have included

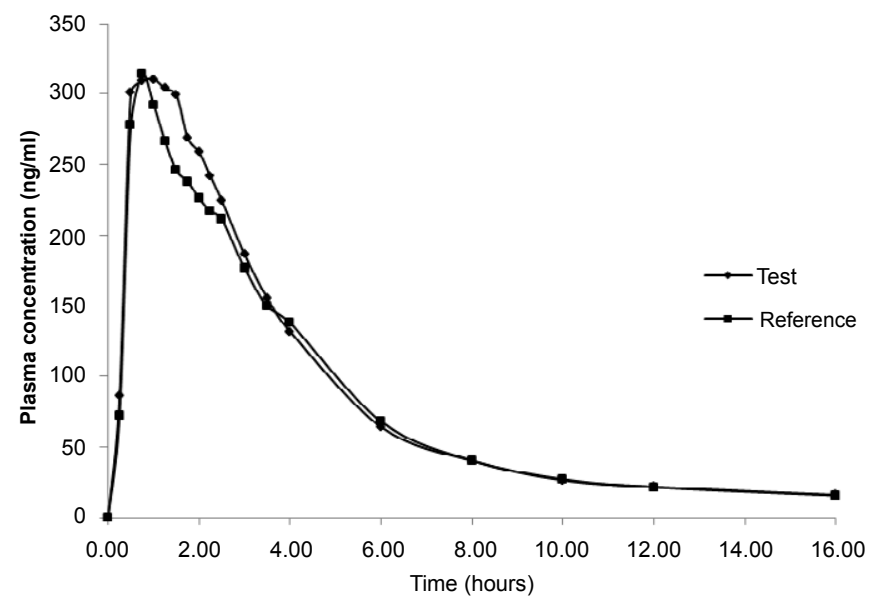

Figure 3: Mean plasma concentrations $(\mathrm{ng} / \mathrm{ml})$ of sildenafil versus time (hours) after a single oral dose of $100 \mathrm{mg}$ sildenafil tablet $(n=30)$ under fasting conditions.

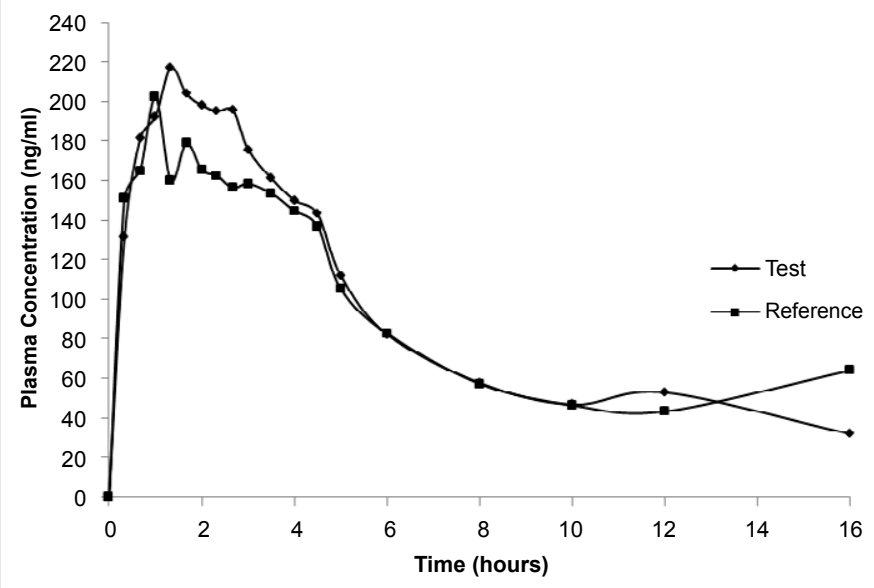

Figure 4: Mean plasma concentrations ( $\mathrm{ng} / \mathrm{ml}$ ) of sildenafil versus time (hours) after a single oral dose of $100 \mathrm{mg}$ sildenafil tablet $(n=32)$ under fed conditions. 
Citation: Qaisi AM, Tutunji L, Tutunji M, Mohsen MA (2015) The Role of Metabolite in Bioequivalence Decision Making. J Bioequiv Availab 7: 158-163. doi:10.4172/jbb.1000232

\begin{tabular}{|c|c|c|c|c|}
\hline (A) Enalaprila & \multicolumn{2}{|r|}{ Test } & \multicolumn{2}{|c|}{ Reference } \\
\hline Parameter (unit) & Mean & Range & Mean & Range \\
\hline Cmax (ng/ml) & 80.43 & $9.49-177.68$ & 73.86 & $37.55-140.32$ \\
\hline $\mathrm{AUC}_{0 \rightarrow \text { last }}(\mathrm{ng} \cdot \mathrm{hr} / \mathrm{ml})$ & 129.71 & $58.82-302.67$ & 122.10 & $70.50-205.92$ \\
\hline$A U C_{0 \rightarrow \text { inf }}(\mathrm{ng} \cdot \mathrm{hr} / \mathrm{ml})$ & 134.15 & $64.39-307.29$ & 126.88 & $74.25-209.15$ \\
\hline Parameter (unit) & Median & Range & Median & Range \\
\hline $\mathbf{T}_{\max }$ (hours) & 1.00 & $0.75-3.67$ & 0.75 & $0.50-2.33$ \\
\hline $\mathrm{T}_{1 / 2}$ (hours) & 1.08 & $0.62-1.75$ & 1.24 & $0.75-2.36$ \\
\hline (B) Enalaprilat & \multicolumn{2}{|r|}{ Test } & \multicolumn{2}{|c|}{ Reference } \\
\hline Parameter (unit) & Mean & Range & Mean & Range \\
\hline Cmax (ng/ml) & 43.25 & $19.40-73.01$ & 44.18 & $21.95-61.93$ \\
\hline$A \cup C_{0 \rightarrow \text { last }}(\mathrm{ng} \cdot \mathrm{hr} / \mathrm{ml})$ & 399.41 & $210.45-646.50$ & 390.93 & $217.20-626.51$ \\
\hline$A U C_{0 \rightarrow \text { inf }}(\mathrm{ng} \cdot \mathrm{hr} / \mathrm{ml})$ & 430.04 & $229.71-678.64$ & 420.12 & $239.45-697.34$ \\
\hline Parameter (unit) & Median & Range & Median & Range \\
\hline $\mathbf{T}_{\max }$ (hours) & 4.00 & $2.67-6.00$ & 4.33 & $2.33-6.00$ \\
\hline$T_{1 / 2}$ (hours) & 14.00 & $4.73-33.60$ & 12.28 & $4.94-28.76$ \\
\hline
\end{tabular}

Table 1: Pharmacokinetic parameters of enalapril and its active metabolite enalaprilat after a single oral dose of $20 \mathrm{mg}$ enalapril tablets under fasting conditions $(n=26)$.

\begin{tabular}{|c|c|c|c|c|}
\hline \multirow{2}{*}{$\begin{array}{l}\text { (A) Sildenafil } \\
\text { Parameter (unit) }\end{array}$} & \multicolumn{2}{|r|}{ Test } & \multicolumn{2}{|c|}{ Reference } \\
\hline & Mean & Range & Mean & Range \\
\hline Cmax (ng/ml) & 411.83 & $152.70-851.38$ & 447.83 & $176.09-1030.35$ \\
\hline$A U C_{0 \rightarrow \text { last }}(\mathrm{ng} \cdot \mathrm{hr} / \mathrm{ml})$ & 1322.93 & $560.84-2562.09$ & 1250.28 & $567.94-2301.67$ \\
\hline$A U C_{0 \rightarrow \text { inf }}(\mathrm{ng} \cdot \mathrm{hr} / \mathrm{ml})$ & 1405.92 & $621.11-2711.13$ & 1328.27 & $616.21-2339.35$ \\
\hline Parameter (unit) & Median & Range & Median & Range \\
\hline $\mathrm{T}_{\max }$ (hours) & 0.75 & $0.50-2.25$ & 0.75 & $0.25-4.00$ \\
\hline$T_{1 / 2}$ (hours) & 3.52 & $2.11-4.87$ & 3.44 & $2.14-5.80$ \\
\hline $\begin{array}{l}\text { (B) N-desmethyl } \\
\text { Sildenafil }\end{array}$ & \multicolumn{2}{|r|}{ Test } & \multicolumn{2}{|c|}{ Reference } \\
\hline Parameter (unit) & Mean & Range & Mean & Range \\
\hline Cmax (ng/ml) & 211.49 & $90.82-390.15$ & 208.41 & $69.12-346.13$ \\
\hline $\mathrm{AUC}_{0 \rightarrow \text { last }}(\mathrm{ng} \cdot \mathrm{hr} / \mathrm{ml})$ & 726.63 & $666.31-1440.54$ & 652.82 & $354.26-1262.08$ \\
\hline $\mathrm{AUC}_{0 \rightarrow \mathrm{inf}}(\mathrm{ng} \cdot \mathrm{hr} / \mathrm{ml})$ & 758.70 & $426.79-1471.22$ & 687.28 & $372.24-1434.64$ \\
\hline Parameter (unit) & Median & Range & Median & Range \\
\hline $\mathrm{T}_{\max }$ (hours) & 0.88 & $0.50-2.00$ & 0.88 & $0.50-4.00$ \\
\hline$T_{1 / 2}$ (hours) & 5.64 & $4.13-8.43$ & 5.81 & $4.03-15.07$ \\
\hline
\end{tabular}

Table 2: Pharmacokinetic parameters of sildenafil and its active metabolite $\mathrm{N}$-desmethyl sildenafil after a single oral dose of $100 \mathrm{mg}$ sildenafil tablets under fasting conditions $(n=30)$.

simulation studies as well as real data from bioequivalence studies, it was recommended that in the absence of the information on relative variability of absorption and first-pass process, the parent drug and metabolite data be included for determining bioequivalence assuming that the metabolite may play an important role in the determination of efficacy and safety of the drug. With regards to the estimation of bioequivalency using metabolite data for immediate release formulations for drugs exhibiting linear pharmacokinetics and no first-pass effect, simulation results were generated for $\mathrm{C}_{\max }$ based on the formation and excretion rate-limited pharmacokinetic models with absorption rate constants obtained from bivariate normal distributions with specified random errors. The results indicated that the bioequivalence decision using $\mathrm{C}_{\max }$ of the parent drug and metabolite were independent of the metabolite models. However, differences in outcomes were clearly evident depending on the use of either $\mathrm{C}_{\max }$ values of the parent drug or the metabolite. This was attributed to the reduced effect of the absorption process for the parent drug or the formation of the metabolite.

The above resulted in an apparent lower intra-subject variability for $\mathrm{C}_{\max }$ of the metabolite, and as a consequence, a smaller confidence interval for the metabolite compared with the parent drug.

The present study, conducted three bioequivalence studies by investigating test and reference drug products after dosing with 20

\begin{tabular}{|c|c|c|c|c|}
\hline \multirow{2}{*}{$\begin{array}{l}\text { (A) Sildenafil } \\
\text { Parameter (unit) }\end{array}$} & \multicolumn{2}{|r|}{ Test } & \multicolumn{2}{|r|}{ Reference } \\
\hline & Mean & Range & Mean & Range \\
\hline Cmax (ng/ml) & 360.14 & $166.63-561.53$ & 336.29 & $140.46-581.91$ \\
\hline$A U C_{0 \rightarrow \text { last }}(\mathrm{ng} \cdot \mathrm{hr} / \mathrm{ml})$ & 1361.07 & $822.20-2818.85$ & 1210.05 & $634.89-3150.15$ \\
\hline$A U C_{0 \rightarrow \text { inf }}(\mathrm{ng} \cdot \mathrm{hr} / \mathrm{ml})$ & 1444.43 & $857.53-2844.49$ & 1291.66 & $714.77-3314.72$ \\
\hline Parameter (unit) & Median & Range & Median & Range \\
\hline$T_{\max }$ (hours) & 1.00 & $0.33-4.50$ & 1.84 & $0.33-8.00$ \\
\hline$T_{1 / 2}$ (hours) & 2.72 & $1.52-5.45$ & 2.92 & $1.37-5.35$ \\
\hline $\begin{array}{l}\text { (B) N-desmethyl } \\
\text { Sildenafil }\end{array}$ & \multicolumn{2}{|r|}{ Test } & \multicolumn{2}{|c|}{ Reference } \\
\hline Parameter (unit) & Mean & Range & Mean & Range \\
\hline Cmax (ng/ml) & 168.91 & $83.89-362.34$ & 158.60 & $64.55-406.17$ \\
\hline$A U C_{0 \rightarrow \text { last }}(\mathrm{ng} \cdot \mathrm{hr} / \mathrm{ml})$ & 645.57 & $313.29-1667.71$ & 561.65 & $260.71-1586.38$ \\
\hline$A U C_{0 \rightarrow \text { inf }}(\mathrm{ng} \cdot \mathrm{hr} / \mathrm{ml})$ & 690.90 & $333.17-1773.97$ & 615.48 & $291.65-1647.82$ \\
\hline Parameter (unit) & Median & Range & Median & Range \\
\hline $\mathbf{T}_{\max }$ (hours) & 1.33 & $0.67-4.50$ & 2.00 & $0.67-4.50$ \\
\hline$T_{1 / 2}$ (hours) & 3.75 & $1.98-6.38$ & 3.95 & $1.92-8.38$ \\
\hline
\end{tabular}

Table 3: Pharmacokinetic parameters of sildenafil and its active metabolite $\mathrm{N}$-desmethyl sildenafil after a single oral dose of $100 \mathrm{mg}$ sildenafil tablets under fed conditions $(n=32)$

(A) Enalapril prodrug

\begin{tabular}{|c|c|c|c|c|c|c|c|}
\hline No & $\begin{array}{c}\text { PK } \\
\text { Parameter }\end{array}$ & $\begin{array}{c}\text { Point } \\
\text { Estimate } \\
\text { (Ratio of } \\
\text { geometric } \\
\text { mean \%) }\end{array}$ & $\begin{array}{c}\text { Lower } \\
\text { Limit }\end{array}$ & $\begin{array}{c}\text { Upper } \\
\text { Limit }\end{array}$ & CV (\%) & Power & Result \\
\hline $\mathbf{1}$ & $\begin{array}{c}\text { AUC } \\
\text { (ng.hr/ml) }\end{array}$ & 103.731 & 96.928 & 111.010 & 14.324 & 99.834 & BE \\
\hline $\mathbf{2}$ & $\begin{array}{c}\text { AUC } \\
\text { (ng.hrinf }\end{array}$ & 104.088 & 97.004 & 111.689 & 14.891 & 99.634 & BE \\
\hline $\mathbf{3}$ & $\begin{array}{c}\mathbf{C}_{\max } \\
\text { (ng/ml) }\end{array}$ & 107.576 & 95.637 & 121.004 & 25.099 & 67.994 & BE \\
\hline
\end{tabular}

(B) Enalaprilat (active metabolite)

\begin{tabular}{|c|c|c|c|c|c|c|c|}
\hline No & $\begin{array}{c}\text { PK } \\
\text { Parameter }\end{array}$ & $\begin{array}{c}\text { Point } \\
\text { Estimate } \\
\text { (Ratio of } \\
\text { geometric } \\
\text { mean \%) }\end{array}$ & $\begin{array}{c}\text { Lower } \\
\text { Limit }\end{array}$ & $\begin{array}{c}\text { Upper } \\
\text { Limit }\end{array}$ & CV (\%) & Power & Result \\
\hline $\mathbf{1}$ & $\begin{array}{c}\text { AUC } \\
\text { (ng.hr/ml) }\end{array}$ & 99.644 & 94.644 & 105.591 & 11.537 & 99.999 & BE \\
\hline $\mathbf{2}$ & $\begin{array}{c}\text { AUC } \\
\text { (ng.hrinf }\end{array}$ & 100.507 & 95.244 & 106.061 & 11.338 & 99.999 & BE \\
\hline $\mathbf{3}$ & $\begin{array}{c}\text { ( } \mathbf{C}_{\text {max }} \\
\text { (ng/ml) }\end{array}$ & 94.890 & 88.550 & 101.684 & 16.900 & 99.319 & BE \\
\hline
\end{tabular}

(C) Combination (sum of the parent drug and its active metabolite)

\begin{tabular}{|c|c|c|c|c|c|c|c|}
\hline No & $\begin{array}{c}\text { PK } \\
\text { Parameter }\end{array}$ & $\begin{array}{c}\text { Point } \\
\text { Estimate } \\
\text { (Ratio of } \\
\text { geometric } \\
\text { mean \%) }\end{array}$ & $\begin{array}{c}\text { Lower } \\
\text { Limit }\end{array}$ & $\begin{array}{c}\text { Upper } \\
\text { Limit }\end{array}$ & CV (\%) & Power & Result \\
\hline $\mathbf{1}$ & $\begin{array}{c}\text { AUC } \\
\text { (nM.hr) }\end{array}$ & 101.674 & 95.921 & 107.772 & 12.285 & 99.999 & BE \\
\hline $\mathbf{2}$ & $\begin{array}{c}\text { AUC } \\
\text { (nM.hr) }\end{array}$ & 100.824 & 94.225 & 107.886 & 12.296 & 99.984 & BE \\
\hline $\mathbf{3}$ & $\begin{array}{c}\mathbf{C}_{\text {max }} \\
\text { (nM) }\end{array}$ & 104.819 & 96.773 & 113.533 & 14.007 & 97.872 & BE \\
\hline
\end{tabular}

$\mathrm{BE}=$ Bioequivalent

Table 4: Statistical Result of enalapril, its active metabolite enalaprilat, and their combination under fasting conditions $(n=26)$. 


\begin{tabular}{|c|c|c|c|c|c|c|c|}
\hline \multicolumn{2}{|c|}{ (A) Sildenafil prodrug } & & & \\
\hline No & $\begin{array}{c}\text { PK } \\
\text { Parameter }\end{array}$ & $\begin{array}{c}\text { Point } \\
\text { Estimate } \\
\text { (Ratio of } \\
\text { geometric } \\
\text { mean \%) }\end{array}$ & $\begin{array}{c}\text { Lower } \\
\text { Limit }\end{array}$ & $\begin{array}{c}\text { Upper } \\
\text { Limit }\end{array}$ & CV (\%) & Power & Result \\
\hline $\mathbf{1}$ & $\begin{array}{c}\text { AUC } \\
\text { (ng.hr/ml) }\end{array}$ & 105.646 & 97.036 & 115.016 & 19.353 & 95.239 & BE \\
\hline $\mathbf{2}$ & $\begin{array}{c}\text { AUC } \\
\text { (ng.hr/mf }\end{array}$ & 105.376 & 97.370 & 114.039 & 17.970 & 97.577 & BE \\
\hline $\mathbf{3}$ & $\begin{array}{c}\mathbf{C}_{\text {max }} \\
\text { (ng/ml) }\end{array}$ & 94.446 & 85.029 & 104.905 & 24.399 & 83.928 & BE \\
\hline
\end{tabular}

(B) N-desmethyl Sildenafil (active metabolite)

\begin{tabular}{|c|c|c|c|c|c|c|c|}
\hline No & $\begin{array}{c}\text { PK } \\
\text { Parameter }\end{array}$ & $\begin{array}{c}\text { Point } \\
\text { Estimate } \\
\text { (Ratio of } \\
\text { geometric } \\
\text { mean \%) }\end{array}$ & $\begin{array}{l}\text { Lower } \\
\text { Limit }\end{array}$ & $\begin{array}{l}\text { Upper } \\
\text { Limit }\end{array}$ & CV (\%) & Power & Result \\
\hline 1 & $\begin{array}{l}\text { AUC }{ }_{\text {o-last }} \\
\text { (ng.hr/ml) }\end{array}$ & 111.729 & 106.637 & 117.065 & 10.555 & 99.140 & BE \\
\hline 2 & $\underset{\text { (ng.hr/ml) }}{\mathrm{AUC}_{\text {-inf }}}$ & 111.320 & 105.610 & 117.339 & 11.923 & 97.932 & $B E$ \\
\hline 3 & $\underset{(n g / m l)}{C_{\max }}$ & 111.682 & 91.818 & 111.682 & 22.368 & 96.615 & $\mathrm{BE}$ \\
\hline
\end{tabular}

(C) Combination (sum of the parent drug and its active metabolite)

\begin{tabular}{|c|c|c|c|c|c|c|c|}
\hline No & $\begin{array}{c}\text { PK } \\
\text { Parameter }\end{array}$ & $\begin{array}{c}\text { Point } \\
\text { Estimate } \\
\text { (Ratio of } \\
\text { geometric } \\
\text { mean \%) }\end{array}$ & $\begin{array}{c}\text { Lower } \\
\text { Limit }\end{array}$ & $\begin{array}{c}\text { Upper } \\
\text { Limit }\end{array}$ & CV (\%) & Power & Result \\
\hline $\mathbf{1}$ & $\begin{array}{c}\text { AUC } \\
\text { (nM.hr) }\end{array}$ & 92.842 & 87.105 & 98.957 & 14.468 & 98.814 & BE \\
\hline $\mathbf{2}$ & $\begin{array}{c}\text { AUC } \\
\text { (nM.hr) }\end{array}$ & 92.705 & 86.912 & 98.884 & 14.637 & 98.533 & BE \\
\hline $\mathbf{3}$ & $\begin{array}{c}\mathbf{C}_{\text {max }} \\
\text { (nM) }\end{array}$ & 102.662 & 93.358 & 112.892 & 21.683 & 96.299 & BE \\
\hline
\end{tabular}

$\mathrm{BE}=$ Bioequivalent

Table 5: Statistical Result of sildenafil, its active metabolite $n$-desmethylsildenafil and their combination under fasting conditions $(n=30)$.

mg enalapril tablets under fasting conditions and Sildenafil $100 \mathrm{mg}$ tablets conducted both under fasting and fed conditions. Its results demonstrated that regardless of the drug pharmacokinetics and the level of error, the variability was clearly reduced. This was paralleled by an increase in the power and of course reduction in the sample size. The observed phenomenon may put the role of the metabolite in bioequivalence studies in a totally different perspective. The above was demonstrated both in the enalapril study under fasting conditions as well as in both the fasting and fed bioequivalence studies for sildenafil.

Enalapril is rapidly absorbed from the GIT; the maximum plasma concentration $\left(\mathrm{C}_{\max }\right)$ was attained in about an hour. It is rapidly converted to its active metabolite as the time needed to attain the maximum plasma concentration $\left(\mathrm{C}_{\mathrm{mx}}\right)$ for enalaprilat is 4 hours. Unlike its active metabolite, enalapril is eliminated rapidly due to its short half-life.

The statistical results for $\mathrm{AUC}_{0 \rightarrow \infty}$ of the enalapril bioequivalence study under fasting conditions gave a point estimate of 104.088 (\%) with a lower and upper limits of 97.004 and 111.689 (\%) respectively demonstrating an intrasubject variability of 14.891 and a power of 99.643. Enalaprilat, however, gave a point estimate of 100.507 with lower and upper limits of 95.244 and 106.061 respectively and demonstrating a CV (\%) of 11.338 and a power of 99.999. The CV (\%) was thus reduced for the metabolite. When the combination of the metabolite and the parent drug were evaluated, values were reasonably placed between the parent drug and the metabolite as demonstrated in a point estimate value of 100.824; however, the lower and upper limits were between 94.225 and 107.886 with a $\mathrm{CV}(\%)$ of 12.296 and a power of 99.98 .

With regards to the $\mathrm{C}_{\text {max }}$ results of the enalapril bioequivalence study under fasting conditions, a significant improvement was observed in the variability and power. The $C_{\max }$ values gave a point estimate of 107.576 , while the lower and upper limits were 95.686 and 121.004 respectively, whereas the CV (\%)| was 25.099 with a power of 67.004 . As for the metabolite enalaprilat, the point estimate was 94.890 , while the lower and upper limits were 88.550 and 101.684 respectively. The CV (\%) was 14.607, while the estimated power was 99.319. AS observed, there was a significant improvement in the estimated power of the metabolite. The notable improvement in the $\mathrm{CV}(\%)$ of the combined drug and metabolite results produced a CV(\%) of 16.900 and a power of 92.872 .

As shown from the pharmacokinetic parameters listed in Table 2 for the bioequivalence study under fasting conditions, Sildenafil is absorbed rapidly as indicated by a short $\mathrm{T}_{\max }$ of 0.75 hours. It is rapidly converted to its active metabolite as the $\mathrm{T}_{\max }$ of $\mathrm{N}$-desmethyl Sildenafil is about 0.88 hours. Both the drug and its active metabolite have relatively short half-lives indicating that both compounds are eliminated quickly.

As shown from pharmacokinetic parameters of sildenafil its active metabolite under fed conditions (Table 3), Sildenafil absorption was delayed as $\mathrm{T}_{\max }$ increased from 0.75 hours under fasting conditions to 1.82 hours under fed conditions. The maximum concentration $\left(\mathrm{C}_{\max }\right)$

\begin{tabular}{|c|c|c|c|c|c|c|c|}
\hline \multicolumn{8}{|c|}{ (A) Sildenafil prodrug } \\
\hline No & $\begin{array}{c}\text { PK } \\
\text { Parameter }\end{array}$ & $\begin{array}{c}\text { Point } \\
\text { Estimate } \\
\text { (Ratio of } \\
\text { geometric } \\
\text { mean \%) }\end{array}$ & $\begin{array}{l}\text { Lower } \\
\text { Limit }\end{array}$ & $\begin{array}{l}\text { Upper } \\
\text { Limit }\end{array}$ & CV (\%) & Power & Result \\
\hline 1 & $\begin{array}{l}\text { AUC }_{\text {o-last }} \\
\text { (ng.hr/ml) }\end{array}$ & 113.622 & 107.352 & 120.258 & 13.412 & 87.468 & $\mathrm{BE}$ \\
\hline 2 & $\underset{\text { (ng.hr/ml) }}{\mathrm{AUC}_{\text {-inf }}}$ & 112.991 & 106.986 & 119.333 & 12.898 & 92.340 & $B E$ \\
\hline 3 & $\underset{\text { (ng/ml) }}{C_{\max }}$ & 108.003 & 95.732 & 121.848 & 28.950 & 63.755 & $\mathrm{BE}$ \\
\hline
\end{tabular}

(B) N-desmethyl Sildenafil (active metabolite)

\begin{tabular}{|c|c|c|c|c|c|c|c|}
\hline No & $\begin{array}{c}\text { PK } \\
\text { Parameter }\end{array}$ & $\begin{array}{c}\text { Point } \\
\text { Estimate } \\
\text { (Ratio of } \\
\text { geometric } \\
\text { mean \%) }\end{array}$ & $\begin{array}{c}\text { Lower } \\
\text { Limit }\end{array}$ & $\begin{array}{c}\text { Upper } \\
\text { Limit }\end{array}$ & CV (\%) & Power & Result \\
\hline $\mathbf{1}$ & $\begin{array}{c}\text { AUC } \\
\text { (ng.last }\end{array}$ & 117.634 & 112.585 & 122.910 & 10.3446 & 74.403 & BE \\
\hline $\mathbf{2}$ & $\begin{array}{c}\text { AUC } \\
\text { (ng.hrinf }\end{array}$ & 115.031 & 110.093 & 120.191 & 10.348 & 93.351 & BE \\
\hline $\mathbf{3}$ & $\begin{array}{c}\mathbf{C}_{\max } \\
\text { (ng/ml) }\end{array}$ & 108.578 & 98.403 & 119.805 & 23.458 & 76.826 & $\mathrm{BE}$ \\
\hline
\end{tabular}

(C) Combination (sum of the parent drug and its active metabolite)

\begin{tabular}{|c|c|c|c|c|c|c|c|}
\hline No & $\begin{array}{c}\text { PK } \\
\text { Parameter }\end{array}$ & $\begin{array}{c}\text { Point } \\
\text { Estimate } \\
\text { (Ratio of } \\
\text { geometric } \\
\text { mean \%) }\end{array}$ & $\begin{array}{c}\text { Lower } \\
\text { Limit }\end{array}$ & $\begin{array}{c}\text { Upper } \\
\text { Limit }\end{array}$ & CV (\%) & Power & Result \\
\hline $\mathbf{1}$ & $\begin{array}{c}\text { AUC } \\
\text { (nM.hr) }\end{array}$ & 117.775 & 112.786 & 122.985 & 10.208 & 73.920 & BE \\
\hline $\mathbf{2}$ & $\begin{array}{c}\text { AUC } \\
\text { (nM.hrf }\end{array}$ & 115.116 & 110.251 & 120.197 & 10.184 & 93.627 & BE \\
\hline $\mathbf{3}$ & $\begin{array}{c}\mathbf{C}_{\text {max }} \\
\text { (nM) }\end{array}$ & 108.573 & 98.400 & 119.798 & 23.454 & 76.860 & BE \\
\hline
\end{tabular}

$\mathrm{BE}=$ Bioequivalent

Table 6: Statistical Result of sildenafil, its active metabolite n-desmethylsildenafil, and their combination under fed conditions $(n=32)$. 
reached decreased by $25 \%$ from $447.83 \mathrm{ng} / \mathrm{ml}$ to $337.29 \mathrm{ng} / \mathrm{ml}$ due to the presence of food. While the total amount absorbed also decreased by about 3\% due to food effect as reflected by AUC which decreased from $1328.27 \mathrm{ng} . \mathrm{hr} / \mathrm{ml}$ to $1291.66 \mathrm{ng} . \mathrm{hr} / \mathrm{ml}$. AS for the active metabolite $\mathrm{N}$-desmethyl sildenafil, both the $\mathrm{C}_{\max }$ and AUC decreased by $24 \%$ and $10 \%$ respectively due to the presence of food. $\mathrm{C}_{\text {max }}$ of $\mathrm{N}$-desmethyl sildenafil decreased from $208.41 \mathrm{ng} / \mathrm{ml}$ under fasting conditions to $158.60 \mathrm{ng} / \mathrm{ml}$ under fed conditions, while AUC decreased from 687.28 ng.hr/ml under fasting conditions to 615.48 under fed conditions.

Similar conclusions can be drawn from the statistical analyses of the sildenafil bioequivalence studies both under fasting and fed conditions. The above mentioned results positively affect the estimated sample size, without adversely affecting the safety or the efficacy of the mentioned drugs. The mentioned phenomena have never been depicted in previous reports which discussed the role of the metabolite.

In bioequivalence studies, AUC and $\mathrm{C}_{\max }$ values are regarded as independent parameters. The acceptance region, using the confidence interval approach is predefined, and depends on the variability of each parameter. The results show that AUC and $\mathrm{C}_{\max }$ values are highly correlated, regardless of the sample size. This may impact the power to establish equivalence or, no effect for both parameters.

To evaluate the probability (p) of declaring equivalence, both univariate and bivariate confidence interval approach were investigated on simulated datasets using SAS, and were compared to the present study results. The $P$ values decreased with increasing $r$ values, regardless of the sample size [12-15].

Furthermore, using the univariate analysis, the p-values of meeting 0.8-1.25 limits for declaring equivalence were higher. The bivariate confidence interval approach with an acceptance range of: 0.75-1.33, however, demonstrated lower p-values, and thus is recommended for evaluating Bioequivalence for both low and highly variable drugs, in addition to evaluating the parent drugs and their corresponding metabolites since these are measured in the same sample and are a function of the relative intra- subject variability $[16,17]$.

The present study demonstrated that the role of the metabolite should be revisited and should be looked upon in terms of reducing intra-subject variability particularly for $\mathrm{C}_{\max }$ data which directly impacts the statistical design of bioequivalence studies, in addition, to the prediction of sample size without compromising power. The study also gives more impact into the design of highly variable drugs.

\section{Acknowledgement}

This work was conducted during the sabbatical leave of A.M. Qaisi, The University of Jordan, Amman, Jordan.

\section{References}

1. Mahmood I (1998) Assessment of metabolites in bioequivalence studies: should bioequivalence criteria be applied on the sum of parent compound and metabolite? Int J Clin Pharmacol Ther 36: 540-544

2. Karalis V, Macheras $P$ (2010) Examining the role of metabolites in bioequivalence assessment. J Pharm Pharm Sci 13: 198-217.

3. Srinivas NR (2009) Considerations for metabolite pharmacokinetic data in bioavailability/bioequivalence assessments. Overview of the recent trends. Arzneimittelforschung 59: 155-165.

4. Jackson AJ, Robbie G, Marroum P (2004) Metabolites and bioequivalence: past and present. Clin Pharmacokinet 43: 655-672.

5. Arafat T, Awad R, Hamad M, Azzam R, Al-Nasan A, et al. (2005) Pharmacokinetics and pharmacodynamics profiles of enalapril maleate in healthy volunteers following determination of enalapril and enalaprilat by two specific enzyme immunoassays. J Clin Pharm Ther 30: 319-328.

6. Gu Q, Chen X, Zhong D, Wang Y (2004) Simultaneous determination of enalapril and enalaprilat in human plasma by liquid chromatography-tandem mass spectrometry. J Chromatogr B Analyt Technol Biomed Life Sci 813: 337 342

7. Protoles A Terleira A, Almeida S, Garcia-Arenillas M, Caturla MC, et al. (2004) Bioequivalence study of two formulations of enalapril, at a single oral dose of $20 \mathrm{mg}$ (tablets): A randomized, two-way, open-label, crossover study in healthy volunteers. Curr Ther Res Clin Exp 65: 34-46.

8. Croom KF, Curran MP (2008) Sildenafil: a review of its use in pulmonary arterial hypertension. Drugs 68: 383-397.

9. Langtry HD, Markham A (1999) Sildenafil: a review of its use in erectile dysfunction. Drugs 57: 967-989.

10. Wang P, Liang Y, Chen B, Zhou N, Yi L, et al. (2007) Simultaneous determination of enalapril and enalaprilat in human plasma by LC-MS: application to a bioequivalence study. Chromatographia 65: 209-215

11. Pisarev VV, Moskaleva NE, Zverkov YB, Smironova LB, Belolipetskaya VG et al. (2005) HPLC/MS determination of enalapril and enalaprilat in the blood plasma. Pharmaceutical Chemistry Journal 39: 49-52.

12. Thongnopnua $P$, Poeaknapo $C$ (2005) High-performance liquid chromatographic determination of enalapril in human plasma by enzyme kinetic analytical method. J Pharm Biomed Anal 37: 763-769.

13. Najib NM, Idkaidek $N$, Adel A Admour I, Astigarraga RE, et al. (2003) Bioequivalence evaluation of two brands of enalapril $20 \mathrm{mg}$ tablets (Narapril and Renitec) in healthy human volunteers. Biopharm Drug Dispos 24: 315-320.

14. Lee J, Son J, Lee M, TaeLee K, Kim D(2003) Simultaneous quantitation of enalapril and enalaprilat in human plasma byu 96-well solid phase extraction and liquid chromatography / tandem mass spectrometry. Rapid Commun. Mass Spectrom 17: 1157-1162.

15. Tripathi AS, Sheikh I, Dewani AP, Shelke PG, Bakal RL, et al. (2013) Development and validation of RP-HPLC method for sildenafil citrate in rat plasma-application to pharmacokinetic studies. Saudi Pharm J 21: 317-321.

16. Eerkes A, Addison T, Jaidong W(2002) Simultaneous assay of sildenafil and desmethylsildenafil in human plasma using liquid chromatography-tandem mass spectrometry on silica column with aqueous organic mobile phase. J Chromatog B 768: 277-284.

17. Sheu MT, Wu AB, Yeh GC, Hsia A, Ho HO (2003) Development of a liquid chromatographic method for bioanalytical applications with sildenafil. J Chromatogr B Analyt Technol Biomed Life Sci 791: 255-262. 